\title{
Ka društveno odgovornom arhitektonskom obrazovanju
}

\author{
Ana Nikezić \\ Univerzitet u Beogradu, Arhitektonski fakultet, Beograd, Srbija \\ e-mail:ana.nikezic@gmail.com
}

\author{
Nataša Janković \\ Univerzitet u Beogradu, Arhitektonski fakultet, Beograd, Srbija \\ e-mail: natasha.jankovic@gmail.com
}

SAŽETAK Tradicionalni sistem visokog obrazovanja posmatra arhitekturu kao umetničku ili pak inženjersku disciplinu, te pojednostavljuje druge aspekte njenog diskursa, kao što su sociološki, ekonomski ili ekološki. Na osnovu rezultata istraživanja izvedenog na Arhitektonskom fakultetu u Beogradu tokom rada na izbornom kursu "Re_Birth: Novi život napuštenih prostora", na Master akademskim studijama, ovaj rad ispituje kako, na osnovu čega i u kojoj meri izmeštanje arhitektonskog obrazovanja iz strogo akademskih okvira može da doprinese formiranju svestranog i društveno odgovornog arhitekte. Uloga ovog kursa bila je da postavi konkretno mesto i zajednicu koja ga determiniše kao strukturalni deo arhitektonskog mehanizma, nasuprot posmatranju konteksta kao pukog fizičkog okvira, a društvene zajednice kao otežavajuće prepreke. Sumirajući metod rada, te interpretativni potencijal zadatog tematskog i prostornog okvira kroz studentske radove, istraživanje kroz diskusiju ukazuje na ulogu metode "učenje na osnovu mesta" u arhitektonskom obrazovanju, te na moguće načine učvršćivanja veze između konkretnog mesta, njegove lokalne zajednice i arhitekture kao profesije. U tom smislu, odgovornost arhitekture kao profesije je da formira uslove za otvaranje dijaloga između potrebe da se istovremeno poboljša nasleđe i unapredi lokalna zajednica. Rezultati istraživanja ukazuju na tri činjenice: arhitektura kao disciplina može se menjati kroz restruktuiranje odnosa prema čoveku i redefinisanje odnosa prema kontekstu, pri čemu na taj način postaje alat koji podstiče društvenu interakciju; zatim, materijalna i senzitivna svojstva arhitekture menjaju se u odnosu na način na koji se određeno mesto koristi i značenja koja nosi, formirajući na taj način kulturni pejzaž koji je oblikovan kroz okvir nadrealne materijalnosti, gde su zvuk, miris, svetlost i senka, dodir i psihološki doživljaj prostora vodeći elementi arhitektonske intervencije; i na kraju - konkretno mesto se oblikuje kroz optimizaciju arhitektonske intervencije u odnosu na lokalno stanovništvo i kulturne i istorijske reference.

Ključne riječi: arhitektonsko obrazovanje, društvena odgovornost, specifičnosti mesta. 


\section{Uvod: Arhitektonsko obrazovanje}

Tradicionalni sistem visokog obrazovanja posmatra arhitekturu kao umetničku ili pak inženjersku disciplinu, te pojednostavljuje druge aspekte njenog diskursa, kao što su sociološki, ekonomski ili ekološki. Tradicionalne metode izvođenja nastave dominantno su zasnovane na usvajanju hipotetičkih i apstraktnih veština, kao i na usvajanju pojedinačnih znanja. Postojeći metodi učenja često ignorišu kontekstualne komponente sredine u kojoj arhitektura deluje. Ovakav pristup edukaciji arhitekte nije vođen tumačenjima i vrednovanjima iskustava i percepcije stanovnika i drugih zainteresovanih korisnika konkretnog mesta, te je onemogućen razvoj veština potrebnih za rad u realnim situacijama, gde su uslovi ograničeni, složeni i često kontradiktorni (Salama, 2008.). Proces obrazovanja arhitekata odvija se daleko od realnog društva i vremena, potreba tržišta, a takođe ekoloških problema, čime izostaje prilika za pripremu studenata za stvarne probleme sa kojima će se susresti u praksi i za suočavanje sa odgovornostima koje ih čekaju u odnosu na društvo u celini.

Kako profesionalnu kompetentnost i sposobnost budućih stručnjaka u praksi u velikoj meri određuje edukativni proces, obrazovanje budućih arhitekata treba da, pored logičke i estetičke, ima i etičku dimenziju (Soria Lopez, 2006.). Cilj ove dimenzije arhitektonskog obrazovanja je da osvesti društvene, kulturološke, ekološke, političke i ekonomske aspekte problema okruženja u kome ce arhitekta delovati. Imajući u vidu činjenicu da istraživanje i aktiviranje konkretnog prostora znači saradnju sa lokalnom zajednicom, ali i sa svim drugim akterima u procesu razvoja grada zainteresovanim za konkretan prostorni okvir (Mišetić i Ursić, 2010.), neophodno je konstantno preplitanje akademskog i istraživačkog pristupa, sa permanentnim izmeštanjem iz arhitektonskog u druge diskurse. Arhitektonska intervencija koja ignoriše lokalni kontekst i zajednicu rizikuje da proizvede i poveća probleme, pre nego da ih reši (Williams, 2007.). Polje društvenih nauka pred nas stavlja potrebu za znatno širim razumevanjem sveta koji nas okružuje (Salama, 2008.) i fokusiranjem na sociološki diskurs, čiji predmet interesovanja podrazumeva kako istraživanje uslova života stanovništva unutar zajednica, tako i kakve posledice po šire okruženje ovi uslovi uzrokuju i kako posledice povratno utiču na ljude (Pušić, 2009.).

"Place-based" učenje teži da prevaziđe granice akademskog učenja koje se bazira na eks-katedra predavanjima i da ga orjentiše ka učenju iz živog iskustva. U ovom istraživanju se „učenje na osnovu mesta“ posmatra onako kako ga i David Sobel (2004.) posmatra, odnosno kao paradigma u edukaciji; kao način razmišljanja pre nego kao novi metod učenja. To je proces u kome se koristi lokalni prostorni i društveni kontekst kao početna premisa za razumevanje opštih koncepata (Sobel, 2004.:7). U ovom istraživanju "place-based" učenje nije samo motivisano željom da se prevaziđe barijera između konceptualnog znanja i življenog iskustva, već teži da ukaže na raznolikost pristupa rešavanju nekog problema, te pokaže svu složenost načina na koji smo povezani sa nekim konkretnim mestom (Edelglass, 2007.). Grunewald i Smith (Grunewald, 2003.) tvrde da ovakav način edukacije omogućava da su studenti istovremeno i kreatori i potrošači znanja gde upravo njihova pitanja i razmišljanja imaju centralnu ulogu u učenju. Dakle "place-based" učenje promoviše 
učenje ukorenjeno u sve ono što nazivamo lokalno i uvek je povezano sa onim što zovemo stvarni svet (Smith, 2002.:589).

$\mathrm{Na}$ osnovu rezultata rada na Arhitektonskom fakultetu u Beogradu na izbornom kursu "Re_Birth: Novi život napuštenih prostora", na Master akademskom studijama, ovaj rad ispituje kako, na osnovu čega i u kojoj meri izmeštanje arhitektonskog obrazovanja iz strogo akademskog okvira može da doprinese formiranju svestranog i društveno odgovornog arhitekte. Sumirajući metod rada, te interpretativni potencijal zadatog tematskog i prostornog okvira kroz studentske radove, istraživanje ukazuje na potencijal ovog pedagoškog principa da izazove rigidnost i ambivalentnost arhitektonskog obrazovanja. Takođe, posredno ukazuje na odgovornost arhitekte prema kontekstu u koji se smešta i društvu kome služi.

\section{Univerzitet u Beogradu, Arhitektonski fakultet}

\section{Master akademske studije; Izborni kurs: RE_BIRTH: novi život napuštenih prostora}

U cilju podsticanja svesti studenata i posredno šire javnosti o konkretnim problemima mesta sa kojima se susreće profesija arhitekte, na Univerzitetu u Beogradu - Arhitektonskom fakultetu, na prvoj godini Master akademskih studija, organizovan je izborni kurs sa idejom da se ispitaju mogućnosti primene interdisciplinarnog pristupa u arhitektonskoj edukaciji sa akcentom na "place- based" metod istraživanje koje tretira stvarne probleme u realnom, društveno-političkom i kulturno- istorijskom okviru. Tema kursa, pod nazivom "RE_BIRTH: novi život napuštenih prostora"1, je afirmacija kulturno-istorijski značajnih ali i zapuštenih i degradiranih centralnih gradskih četvrti. Dakle, namera kursa je da pokaže mogućnosti i potencijal arhitektonske edukacije da kroz zadati formalni okvir ukaže na važnost interdisciplinarnog pristupa, te da učini edukaciju integrativnom, istovremeno akademskom i društveno angažovanom, usmerenom ka brizi o konkretnom mestu.

\section{Prostorni poligon}

Za prostorni poligon odabrana je četvrt Savamale u Beogradu, kao jedna od najstarijih kulturno- istorijskih celina starog Beograda. Tokom stopedeset godina duge istorije, od životnog i sceničnog priobalja tzv. Savskog amfiteatra, pretvorila se u zapušteno područje koje odlikuju teretni saobraćaj, skladišta i zaboravljeni stari zanati. Savamala se nalazi južno od Kalemegdanske tvrđave, u susedstvu Kosančićevog

1 Kurs "RE_BIRTH: novi život napuštenih prostora" traje jedan semestar, odnosno četrnaest radnih nedelja u nastavi i četiri nedelje za rad na terenu. Kurs vodi jedan nastavnik doc. dr Ane Nikezić i jedan koordinator Nataša Janković, student doktorskih studija na istom fakultetu. Na kursu učestvuje do tridesetidvoje studenata. U rad je uvek uključeno od dvoje do četvoro stručnjaka van okvira Arhitektonskog fakulteta, često predstavnici opštinskih i gradskih vlasti kao i predstavnici Urbanističkog zavoda Beograda. 
venca (oba istorijski zaštićena područja) i prostire se duž desne obale reke Save. Iako se nalazi u zoni užeg gradskog jezgra od njega je odsečena. To je deo grada koji se iz životnog pretvorio u napušteno mesto, iz politički i kulturno značajnog u marginalizovano područje, iz formalnog u neformalno, a sada i efemeran urbani ostatak oivičen gustim saobraćajem, okarakterisan društveno marginalizovanim grupama korisnika i stanovnika funkcionalno isključenim iz života grada.

Prilog 1: Mapa užeg centra Beograda sa pozicijom Savamale

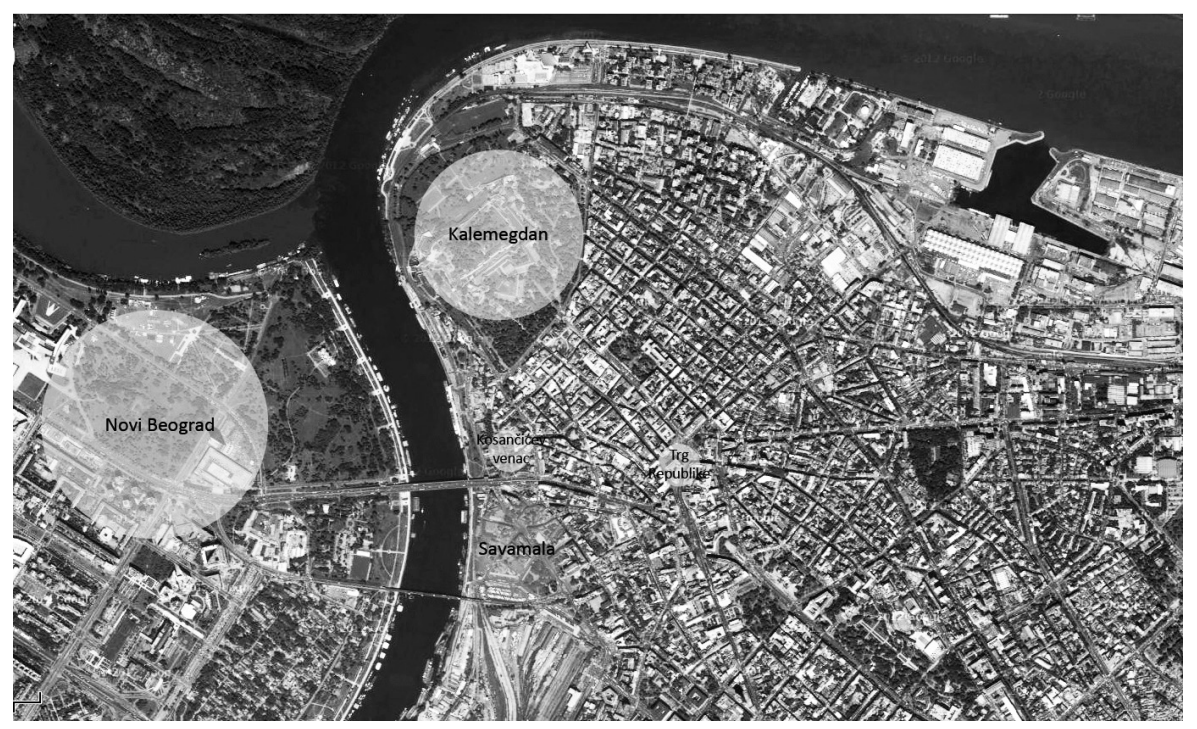

Prva inicijativa aktiviranja ovog područja javila se dvehiljaditih godina otvaranjem Kulturnog centra "Grad", u saradnji sa Kulturnim centrom Holandije, kao prostora za razvoj alternativnih inicijativa u polju kulture. Ubrzo je ovaj prostor postao mesto okupljanja raznorodnih grupa mladih ljudi. Tokom narednih godina, otvoreno je nekoliko klubova i barova, a sa njima je i Savamala ponovo postala zanimljiva. U ovakvim situacijama različite interesne grupe nastoje da ustanove poseban narativ ili verziju događaja kao sredstvo za postizanje sopstvenih ciljeva (Jacobs, 2006 u: Perić i Maruna, 2012.:66). Različiti javni i privatni interesi prepoznali su ovaj potencijal i uočili svoju poziciju u daljem razvoju Savamale, a kroz strategije kreativnog grada (Landry, 2000.; Florida, 2005.; Cooke i Schwartz, ur., 2007.). Od 2012. godine vodeću ulogu u razvoju Savamale ima organizacija Mikser (www.mikser.rs). Posredstvom festivala kao metode delovanja u prostoru (Harcup, 2000.; Hughes, 1999.; Mules, 1993.), Mikser je uspeo da aktivira brojne prostore u okviru Savamale, od kojih su mnogi ostali trajno aktivni, čineći da donedavno zapostavljena Savamala postane aktuelni epicentar društvenog života mladih. Praktično istovremeno sa inicijativama Mikser festivala, pokreće se i inicijativa Gete instituta koja promoviše zaštitu lokalne zajednice i razvoj Savamale u skladu sa njenim potrebama. Tako se u sučeljavanju interesa kreativne industrije i lokalne zajednice razvija aktivan i dinamičan proces u kome arhitektura može, a i treba, da odigra ključnu ulogu. 


\section{Zadatak i metod rada}

Konkretni zadatak istraživanja bio je zadovoljavanje potreba, unapređenje i oplemenjivanje uslova života postojećeg lokalnog stanovništva, te njihovo uključenje u savremene tokove života grada, a kroz reciklažu zaboravljenih ili pak zanemarenih vrednosti koje ovaj prostor u sebi nosi. Osnovni fokus je preispitivanje alternativnih praksi, taktika i dinamike privremenih i umetničkih transformacija napuštenih prostora (onih koji nisu već zauzeti ili u procesu regeneracije), u kojima kolaborativna praksa zadržava prioritet, sa ciljem kreiranja performativnog katalizatora daljih intervencija. Ovako postavljen cilj ističe holistički pristup, u kome je edukacija arhitekte viđena kao mogućnost restrukturiranja kulturnih tradicija kroz razvoj analitičke misli (Altomonte, 2009.), pre svega u smislu razumevanja i povezivanja različitih graničnih disciplina, zatim u smislu podsticanja potreba raznovrsne strukture aktera, i na kraju, u smislu podsticanja saradnje između arhitekte i korisnika prostora. Cilj nije arhitektura u onom utilitarnom smislu, već koncepti za intervencije na granici arhitekture, koji komuniciraju sa prostorom, koji nude taktilni susret nasleđene strukture i savremenih intenzivnih iskustava, doživljenih kroz interakciju nasleđa i čoveka, a probuđenih inspirativnim kulturno, društveno i prostorno aktivnim "arhitektonskim instalacijama".

Pored nastavnika i koordinatora, u istraživanju je učestvovalo preko dvadeset stručnjaka van okvira Arhitektonskog fakulteta koji se bave afirmacijom degradiranih javnih gradskih prostora, bilo da je reč o građanskih inicijativama, umetničkim praksama, ili pak predstavnicima opštine Savski venac na čijoj teritoriji se nalazi Savamala i nadležnih iz Zavoda za zaštitu spomenika kulture grada Beograda, kao tela odgovornog za razvoj ove ambijentalne celine. Pored stručnjaka u radu je učestvovala lokalna zajednica, sa jedne strane i Mikser festival sa druge kao dve interesno oprečne i dominantno zainteresovane strane za konkretne mogućnosti razvoja Savamale (prva za očuvanje duha mesta a druga za njegovu promociju kroz kreativne industrije).

Kako arhitektonska struka podrazumeva istovremeno promišljanje i stvaranje, to je proces rada tekao paralelno kroz debate sa različitim akterima zainteresovanim i na različite načine uključenim u proces afirmacije napuštenih javnih prostora grada sa jedne strane, i samostalan rad na terenu u okviru koga su studenti ispitivali prostorni potencijal lokacije, a takođe i u razgovorima sa lokalnim stanovništvom istraživali njihove potrebe i zahteve sa druge strane. Tokom debata, koje su se odvijale na različitim mestima (od jednog naizgled napuštenog dvorišta Savamale, do renoviranih popularnih noćnih klubova u središtu Savamale), studenti su se upoznali i sa načinom rada određenih institucija, kao npr. Zavoda za zaštitu spomenika, i upoznali sa svim akterima zainteresovanim za razvoj Savamale, od Opštine, preko stanovnika, starih i uplašenih i onih džentrifikovanih, do upravnog odbora lokalne zajednice, zajednice lokalnih zanata, kao i predstavnika Mikser festivala i drugih zainteresovanih grupa potencijalnih korisnika prostora. Tokom samostalnog istraživanja Savamale studenti su u direktnom kontaktu sa lokalnim stanovništvem u razmeri "1:1" ispitivali granice intuitivnog rada i metoda "place-based" učenja. Na kraju, u direktnom dijalogu i kroz kritiku interdisciplinarnog predavačkog tima, sprovedenu u konkretnom prostoru i uz učešće lokalne zajednice podstaknuta je refleksivna praksa i bolji uvid u značaj crteža kao komunikatora. 
Poseban kvalitet bila je višestruka transparentnost procesa rada. Transparentnost procesa rada ogleda se u redovnim javnim prezentacijama sa učesnicima debata, u izložbama koje su studenti organizovali u okviru Edu zone Mikser festivala i u okviru EME3 festivala u Barseloni gde se raspravljalo o konceptima sa lokalnom zajednicom i zainteresovanim stručnjacima i javnim mnjenjem, kao i kroz internet platformu (blog) koju su studenti posebno napravili za ovaj kurs (http://rebirthbelgrade. blogspot.com).

Prilog 2: Rad sa studentima u okviru jedne od diskusija
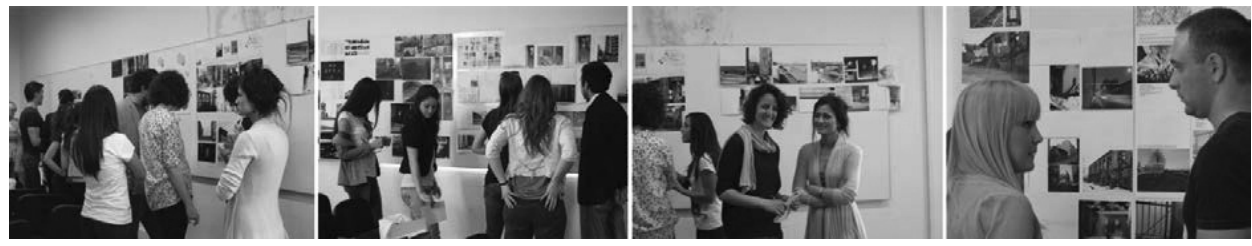

Prilog 3: Studenti u okviru EduZone na Mikser festivalu

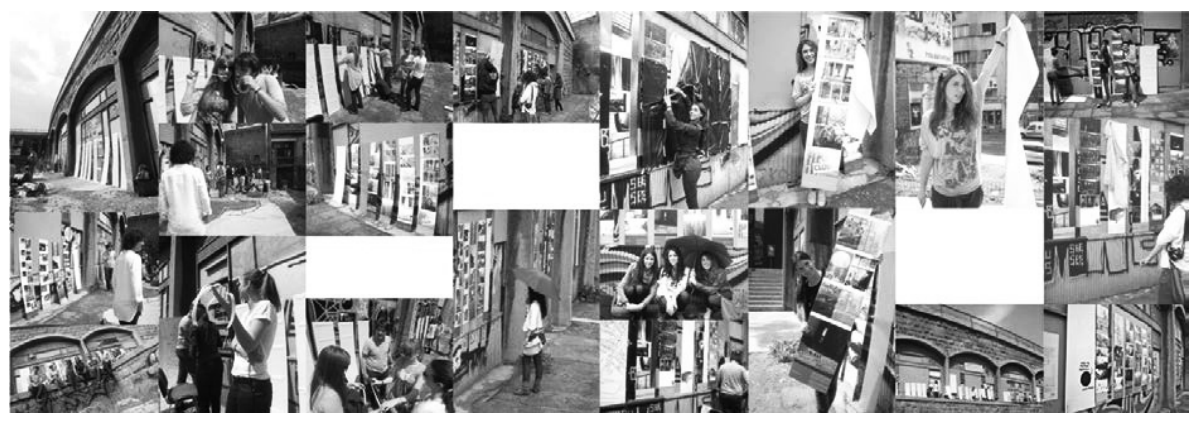

Dinamične i uvek produktivne debate sa jasno definisanim okvirom i ciljem, kao i javne diskusije postavile su pred studente niz pitanja na koje je trebalo odgovoriti. Neka od pitanja bila su:

- Na koji način i pomoću čega konkretan prostor i ljudi koji ga koriste, kao početni impuls, utiču na proces arhitektonske kreacije?

- Koja je uloga arhitekte u razvoju održive zajednice u skladu sa potrebama savremenog grada i društva, da li on gradi, uređuje, organizuje, ili naprosto samo inicira i akcentuje prostore potencijalno podobne za dalji razvoj?

- Koje pouke mogu da se izvuku iz sagledavanja konkretnog prostornog okvira i kako one mogu postati vodeće u konceptualizaciji budućih prostora? Kako ljudi, sa jedne strane, i specifičnosti mesta, sa druge strane, mogu biti iskorišćeni do svog maksimuma, a da se pri tome međusobno ne ugroze ili ponište?

- Da li je fokus na inkorporiranju nasleđenog i zatečenog prostora kao dela arhitektonske kreacije, ili na posmatranju i prevođenju principa upotrebe i svojstava mesta i njegovih značenja u mehanizam za razmišljanje o arhitekturi?

Glavno polje preispitivanja bilo je da li arhitektura može da bude vođena ljudskim iskustvom korišćenja prostora, da li prostor može postati alat svoje transformacije, a stanovništvo kroz društvenu interakciju graditelji prostora. 


\section{Interpretativni potencijal zadatog prostornog i metodološkog okvira}

Bez obzira na prostorni obuhvat i karakter radova, mogu se jasno izdvojiti 4 tematska okvira koji usmeravaju reafirmaciju Savamale. To su: a) Sećanje na Savamalu, b) Metafore Savamale, c) Savamala kao igralište, i d) Savamala kao društveni pejzaž. U prikazanoj tabeli pokazano je po nekoliko predstavnika svake grupe, i to kroz odnos koji koncept gradi prema mestu, sa jedne i lokalnom stanovništvu sa druge strane, kao osnovnim vrednostima Savamale.

Prilog 4: Tabela rezultata studentskih radova

Sećanje na Savamalu obezbeđuje okvir za ponovno otkrivanje istorije Savamale kroz afirmaciju se-
canja na događaje i prostore kojih više nema, a čija se materijalnost prepričava. Arhitektura je nosilac
informacija o prošlom, te ima ulogu vremenskog komunikatora.

Metafore Savamale neguju lokali i tradicionalni stil života kroz sadržinski i prostorni asamblaž koji ga prati. Arhitektura ima ulogu da podstakne očuvanje svakodnevnih rutina koje grade njen identitet.

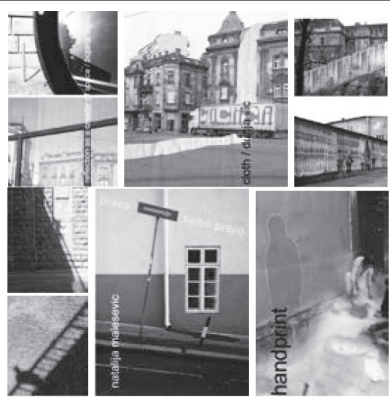

Metafore Savamale:

1) Bojana Bajkić: Reflection as a creator of space, 2) Dunja Simović: Cloth, 3) Miljana Radović: Hiding_unbiding, 4) Jelena Krsmanović: Shadow story of Savamala, 5) Natalija Malešević: Text as a message, 6) Renata Đurić: Handprint, 7) Stanislava Đokić: Fine lace of Savamala, 8) Ana Todosijević: The look of Savamala.

\begin{tabular}{l|l|}
\hline Odnos prema prostoru & $\begin{array}{l}\text { Odnos prema društvenoj } \\
\text { zajednici }\end{array}$ \\
\hline - oživljavanje duha Sava- & - podsetnik da lokalno \\
male kroz optiku filma, & stanovaništvo ima pravo \\
zvuka ili pak mirisa; & živi svojim stilom \\
- prepoznatljivi struk- & života; \\
turni elementi prostora & - atmosfera pripadnosti \\
kao šine, zarđale kapije, \\
slomljeni prozori, kafan- \\
ski čaršafi, zavese, zanat- \\
ski izlozi šetamo; samo sedimo \\
radnje, kafanice, table \\
i drugi dobijaju novu \\
upotrebu i samim tim \\
novu vrednost. & $\begin{array}{l}\text { racijama da ne treba } \\
\text { da ne raskida i ne odriče } \\
\text { se, već da inkorporira } \\
\text { nasleđeno u nove toko- } \\
\text { ve života grada. }\end{array}$ \\
& \\
&
\end{tabular}




Savamala kao igralište aktivira prostor kroz direktnu interakciju čoveka i okruženja, te naglašava
i potencira prepoznata svojstva mesta i ističe njihove granične mogućnosti uključenja u savremene
tokove života grada. Arhitektura ima privremeni karakter i ulogu inicijatora.

Savamala kao društveni pejzaž potencira reciklažu (naglašavanje, oživljavanje, aktiviranje) prepoznatih društvenih i kulturnih obrazaca svakodnevnog života. Arhitektura ima ulogu organizatora načina upotrebe prostora.

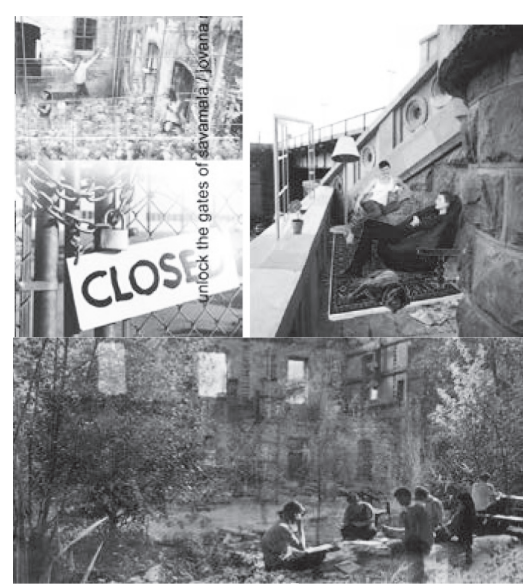

\begin{tabular}{|l|l|}
\hline Odnos prema prostoru & $\begin{array}{l}\text { Odnos prema društvenoj } \\
\text { zajednici }\end{array}$ \\
\hline - infrastruktura javnih & - društveni peizaž je \\
prostora namenjenih & optimizovan kroz urbani \\
interakciji različitih druš- & sadržaj (marker, puto- \\
tvenih grupa; & kaz, sastajalište), kroz \\
- intervencija je ostvare- & uspostavljanje novih \\
na uz dodavanje tek po & prostornih logika, mreža \\
nekog elementa u zate- & društvenih aktivnosti, \\
čene prostore. & pozajmljenih iz raznovr- \\
& snih rutina svakodnev- \\
& nog života Savamale.
\end{tabular}

\section{Savamala kao društveni pejzaž:}

1) Jelena Aranđelović: New root of space, 2) Milica Andrić: Space inbetween, 3) Jovana Mihajlovic: Unlock the gates of Savamala, 4) Milica Simić: (a)VOIDing Savamala, 5) Marija Mladenovic: The Inside story in OUTdoor the OUTside story in INdoor, 6) Nikola Milanović: Bubbles, 7) Tijana Bukvić: Green room. 
Rešenja se razlikuju u pogledu dispozicije, veličine i programskog okvira, ali su ujedinjena u visokom stepenu senzualnosti prema karakteru mesta. Dok koncepcije koje podstiču sećanja Savamale kao dnevnik iznova otvaraju već zaboravljene stranice oživljavajući zaboravljene navike, zanate i načine života, dotle koncepcije koje podstiču metaforu na Savamalu i igralište insistiraju na uključenju prepoznatih elemenata, svojstava, sadržaja i programa u život savremenog grada. Čini se da Savamala kao društveni pejzaž nudi najšire mogućnosti dugoročnog, trajnog razvoja ovog dela grada, integrišući naizgled suprotstavljanje specifične strukture korisnika u jedan prostorni okvir koji svojom fragmentacijom, nudi poželjan okvir za najšire mogućnosti preplitanja, odnosno pojavu novih društvenih mreža. Predstavljeni projekti na različite načine pokazuju svestan pomak prema projektovanju koje govori kroz karakter i vrednosti specifičnog mesta i ljude koji u njemu žive. Arhitektonska intervencija viđena je kao infrastruktura i konstrukt, a ne samo gotova slika, superponiraju se ljudi i prostor, sadržaji i strukture, podržava se kako gradski život metropole, tako i lokalni život Savamale.

Na konceptualnom nivou, reč je o specifičnom osećaju prisustva dualiteta koje Savamala nosi, o uspostavljanju veze nasleđenog i napuštenog (Sećanje na Savamalu), lokalnog i globalnog (Savamala kao društveni pejzaž), trajnog i efemernog (Metafore Savamale), tradicionalnog i avangardnog (Savamala kao igralište), o poistovećivanju estetike lepog i ružnog, o sučeljavanju elitnog i socijalno marginalizovanog.

$\mathrm{Na}$ nivou sadržaja i programa, reč je o minimalnim intervencijama koje se pre svega usmeravaju ka načinima provođenja slobodnog vremena, o načinima da se svakodnevna rutina na trenutak prekine, te da se preispitaju nametnute logike društvenih vrednosti konzumerizma. Rešenja se kreću od onih u kojima je program sveden na minimum, a prostor ograničen pogledom (Sećanje na Savamalu), do onih u kojima su granice čvrsto urezane, a program određen do nivoa mogućih opcija svakodnevnih aktivnosti (Savamala kao društveni pejzaž).

Na nivou reciklaže ambijenata, reč je o konkretnom iskustvu sučeljavanja sa tradicijom i načinom života Savamale i svim njenim, u savremenom životu grada, marginalizovanim vrednostima i kvalitetima, koje je potrebno istaći, označiti, uskladiti, naglasiti ili pak samo negovati. Zahvaljujući istraživanju u graničnim oblastima arhitekture, kao i radu sa konkretnim problemima predmetnog prostora, studenti nisu insistirali na slici koju intervencija nosi, već na karakteru događaja koji pruža. Ovo ukazuje na dublje razumevanje pravih pokretača prostora, te uspostavlja temeljni odnos nasleđene strukture, napuštenih prostora, potreba zainteresovanih grupa korisnika i veza koje ovaj prostor treba i može da uspostavi sa centralnom gradskom zonom, kao mesto aktivnog odmora i uslužnih delatnosti.

Na nivou doživljaja prostora i značenja koje nosi, reč je o dostizanju specifičnog osećaja biti u Savamaloj (Savamala kao igralište), postati deo Savamale (Metafore Savamale), dostići je i saživeti se sa njom (Savamala kao društveni pejzaž).

Oporavak Savamale viđen je kroz ponovno otkrivanje tradicionalnih vrednosti i načina da se bude u skladu sa Savamalom. Održivost se odnosi, pre svega, na podsticaj 
očuvanja nasleđene kulture i tradicionalnog načina života Savamale i rutine koje ona može da neguje kao deo svog prostornog asamblaža. Oporavak Savamale viđen je kroz alternativne načine provođenja slobodnog vremena koji su u skladu sa urbanim načinom života, ali čiji se koreni mogu naći u prostoru Savamale.

Pristupačni i atraktivni za mlađu populaciju, ovi prostori omogućavaju individualni susret korisnika i prostora Savamale, te nov način upoznavanja. Značajni su kao podsticaj razvoja novih društvenih grupa korisnika u skladu sa mogućnostima i karakterom lokalnih vrednosti i društvenih normi.

\section{Diskusija}

Gledano na nivou kursa, kroz interdisciplinarni okvir ponuđenih debata i primenu "place-based" metode učenja kroz samostalan rad sa lokalnim stanovaništvom, studenti su stekli praktična znanja o prepoznavanju značaja ruiniranih i degradiranih mesta, koja ne smeju biti zaboravljena, i o razlici između onoga što je materijalizovani svedok minulih vremena ili procesa i pukog fizičkog ostatka izgrađenog okruženja. Studenti su razumeli da se značaj mesta ne ogleda samo u fizičkoj strukturi, već i u nematerijalnim procesima razvoja o kojima ove strukture svedoče. Imajući u vidu potencijalne metode i prostorne okvire intervencije, kao i osetljivost same lokacije, studenti su postali svesni potencijalne reakcije koju može izazvati njihova akcija, odnosno koja je to nevidljiva granica koju ne smeju preći u procesu svog delovanja. Ona se ne tiče samo fizičke granice između najjednostavnije podele na privatni i javni prostor, već se tiče i "prava" na prostor, bilo da je reč o nasleđenim pravilima ponašanja lokalnog stanovništva ili o novokomponovanim pravilima koje etablirana društvena zajednica ovog distrikta diktira "osvojivši" ovaj prostor. Dakle, ovde je bilo ključno biti svestan mere intervencije i njihovih potencijalnih posledica.

Samo-refleksija je takođe značajan aspekt rada na kursu. Iako su studenti brzo koncipirali svoje intervencije, u diskusijama sa lokalnim stanovništvom i učesnicima debate koncepti su često nailazili na neodobravanje kako zbog hermetičnosti arhitektonskog crteža, tako i zbog čistote arhitektonskog izraza koja nije bila bliska stvarnim akterima prostora. Pitanja i kritike koje su dolazile od stvarnih aktera Savamale, čini se, najefikasnije su ukazivale na probleme arhitektonskih zamisli i omogućile studentima da stvarno uče iz svojih grešaka. Rad u realnom okruženju, učinio je da se granice između života i edukacije zamagle, a odnos između društva i arhitekture postane porozniji.

Umesto da se bave programskih i oblikovnim aspektima arhitektonskog projektovanja, studenti su izazvani konkretnim mestom uronili u sve pore Savamale, upoznajući se sa njenim ritmom, svakodnevnim aktivnostima i stilom života, te gradeći individualni odnos prema njoj. Arhitektonske koncepcije su rezultat direktne i dinamične veze sa okruženjem, razvijene kroz proces upoznavanja, uključivanja, istraživanja i na kraju potencijalne transformacije. Rad na istraživanju je naučio studente da bilo koja arhitektonska koncepcija mora biti dinamična i adaptabilna, a često i pre spontana i intuitivna, nego estetski pročišćena i oblikovno dovršena. 
Istraživanje konkretnog prostornog okvira, sa problemima koje nameće savremeni kontekst i sadašnji trenutak, stvarna saradnja sa lokalnom zajednicom, kao i razumevanje pozicije arhitekture kao alternativne prakse, odredili su meru i opšti karakter prostornih intervencija. U sumiranju rezultata istraživanja, zajedno sa studentima, došlo se do nekoliko generalnih zaključaka koji se odnose na učvršćivanje veze između prostora, lokalne zajednice Savamale i arhitekture:

- Pre svega, uloga arhitekture je promenjena. Ako ponovo promislimo statičku prirodu arhitekture i zamislimo nebrojana stanja između materijalnog i doživljajnog, uloga odgovorne arhitekture je da restruktuira odnos prema čoveku, da redefiniše odnos prema kontekstu i preispita njene raznolike logike. Na taj način, arhitektura postaje alat koji podstiče društvenu interakciju;

- Drugo, istraživanje konkretnog mesta i načina na koji se ono koristi i značenja koja nosi, menja materijalna i senzitivna svojstva arhitekture. Ako preispitamo poziciju kulture kroz fuziju istorijskih referenci i savremene tehnologije, kulturni pejzaž može biti oblikovan kroz okvir nadrealne materijalnosti, gde su zvuk, miris, svetlost i senka, dodir i psihološki doživljaj prostora vodeći elementi arhitektonske intervencije;

- $\quad \mathrm{Na}$ kraju, oporavak mesta viđen je kroz društvenu dimenziju. Kulturni pejzaž se oblikuje kroz optimizaciju arhitektonske intervencije u odnosu na lokalno stanovništvo i prostorne imaginacije u odnosu na burnu istoriju prostora. Ako preispitamo čisto funkcionalnu dimenziju programa i redefinišemo poziciju koju tipologija u arhitekturi ima, očekivanja koja imamo od arhitekture mogu da se promene, te život mesta može postati generator novih intervencija.

\section{Zaključak: Društveno odgovorno arhitektonsko obrazovanje}

Prostori sa istorijskim i kulturnim karakteristikama su najugroženije teme u procesu regeneracije urbanih sredina. $U$ isto vreme, oni su najeksplicitniji pokazatelji dramatičnih uticaja političkog i ekonomskog života. Prema aktuelnom procesu revitalizacije, u pokušaju da se zaštićeni prostori uključe u tokove svakodnevnog života, zaključuje se da je privremeno korišćenje u snažnom kritičkom dijalogu sa korisnikom najpogodnije rešenje. Rezultati pokazuju da male i privremene intervencije, sa pravim pristupom, vođene sinergijom ljudi i nasleđenog konteksta, donose društveno osvešćenu arhitekturu koja naglašava kvalitete od kojih je prostor i nastao. Kako je težište intervencije na onome šta se takvom intervencijom može postići, posebno je bilo značajno da poruka bude nedvosmisleno preneta javnosti u cilju daljeg osvešćivanja o značaju same lokacije, kao i o potencijalu obimom manjih, ali angažovanih arhitektosnkih praksi.

Danas je arhitektonsko obrazovanje u dubokoj krizi koja zahteva radikalno nove pristupe. Akademsko obrazovanje i dalje je esencijalno za razvoj budućih arhitekata. Sa druge strane, akademija sama nije u stanju da pripremi studenta za sve složenije situacije profesionalne prakse. U ovom radu, pokazali smo da primena "place-based" principa kao dopunjujućeg konvencionalnoj praksi arhitektonske edukacije jeste moguća u formalnim okvirima arhitektonskog obrazovanja i realno potrebna u procesu formiranja društveno odgovornog arhitekte. 
Uloga ovog kursa bila je da postavi konkretno mesto i zajednicu koja ga determiniše kao strukturalni deo arhitektonskog mehanizma, nasuprot posmatranju konteksta kao pukog fizičkog okvira, a društvene zajednice kao otežavajuće prepreke. Gledajući na opštem nivou, ova studija uspostavlja interdisciplinarni teorijski i integralni metodološki okvir u dijalogu između revitalizacije kulturno- istorijskih lokaliteta i zaštite duha mesta, osiguravajući antropološke vrednosti u procesu revitalizacije istorijskog nasleđa u kontekstu održivog razvoja. U tom smislu, odgovornost arhitekture kao profesije je da formira uslove za otvaranje dijaloga između potrebe da se istovremeno poboljša nasleđe i unapredi lokalna zajednica.

Izmeštanje arhitektonskog obrazovanje iz čvrstog okvira akademije i školske učionice ponudilo je studentima i njihovim mentorima priliku za novim, drugačijim iskustvom. Osnovne prednosti ovakvog načina rada su neformalni okvir, eksperimentalnost, improvizacija i privremenost; a pre svega integracija teorije i prakse. Dok učionica nudi kognitivni pristup, iskustveno učenje uključuje celokupnu ličnost studenta. Primenjen metod nastave promenio je krajnji rezultat i učinio ga svesnijim i odgovornijim. Zid između arhitektonske edukacije i društva postao je transparentniji, a između intervencije i prostora porozniji.

Zaključak je da težište u arhitektonskoj edukaciji treba izmestiti iz hipotetičkog okvira u realan prostor koji uzima u obzir stvarne karakteristike prostora, njegove složene i često protivrečne probleme, kao i specifične zahteve zajednice koja prostor koristi. Kako bi arhitektonska edukacija postala odgovornija prema društvu i kontekstu u celini, neophodno je da kurikulum bude povezan sa konkretnim mestom i uključen u njegov stvarni život. Na taj način, mesto dobija posebno poziciju u procesu učenja, a arhitektura neku novu poziciju u razvoju grada.

\section{Literatura}

1. Altomonte, S. (2009). Environmental Education for Sustainable Architecture. Review of European Studies, 2 (1): 12-21.

2. Cooke, Ph. i Schwartz, D. (Ed.). (2007). Creative Regions: Technology, Culture and Knowledge Entrepreneurship. London: Routledge.

3. Edelglass, W. (2007). „Philosophy and Place-Based Pedagogies“. Source: (http:// cielearn.org/wpcontent/themes/ciel/docs/Edelglass, \%20Philosophy\%20and\%20 Place- Based\%20Pedagogies.pdf).

4. Florida, R. (2005). Cities and Creative Class. New York: Routledge.

5. Gruenewald, D. A. (2003a). Foundations of Place: A Multidisciplinary Framework for Place-Conscious Education. American Educational Research Journal, 40 (3): 619-654.

6. Gruenewald, D. A. (2003b). Best of Both Worlds: A Critical Pedagogy of Place. Educational Researcher, 32 (4): 3-12.

7. Harcup, T. (2000). Re-Image a Post-Industrial City: The Leeds St. Valentine's Fair as a Civic Spectacle. City, 4 (2): 215-231.

8. Hughes, C. (1999). Urban Revitalization: The Use of Festive Strategies. Leisure Studies, 18 (2): 61-76. 
9. Landry, Ch. (2000). The Creative City. London: Comedia.

10. Mišetić, A. i Ursić, S. (2010). "The Right to the City": An Example of a Struggle to Preserve Urban Identity in Zagreb. Sociologija i prostor. 186 (1): 3-18.

11. Mules, T. (1993). A Special Event as Part of an Urban Renewal Strategy. Festival Management and Event Tourism, 1 (2): 65-67.

12. Perić, A. i Maruna, M. (2012). Predstavnici društvene akcije u procesu regeneracije priobalja - slučaj braunfild lokacije 'Luka Beograd'. Sociologija i prostor, 192 (1): 61-88.

13. Pušić, Lj. (2009). Sociologija okruženja u traženju svog akademskog i istraživačkog profila. Sociologija i prostor, 183 (1): 27-42.

14. Salama, A. (2008). A Theory for Integrating Knowledge in Architectural Design Education. International Journal of Architectural Research, 2 (1): 100-131.

15. Smith, G. (2002). Place-Based Education: Learning to be Where We Are. Phi Delta Kappan, 83 (8): 584-594.

16. Sobel, D. (2004). Place-Based Education: Connecting Classrooms and Communities. Great Barrington, MA: The Orion Society.

17. Soria Lopez, F. J. (2006). Architecture and Nature at the end of the $20^{\text {th }}$ Century: Towards a Dialogical Approach for Sustainable Design in Architecture, in: Broadbent, G. and Brebbia, C. A. (Eds.). Eco-Architecture-Harmonization Between Architecture and Nature. Southampton: WIT Press, 23-33.

18. Williams, K. (2007). Can Urban Intensification Contribute to Sustainable Cities? Preuzeto sa: (http://unpan1.un.org/intradoc/groups/public/documents/APCITY/UNPAN026009.pdf). 15.10.2012. 


\title{
Ana Nikezić
}

Faculty of Architecture, University of Belgrade, Belgrade, Serbia

e-mail:ana.nikezic@gmail.com

Nataša Janković

Faculty of Architecture, University of Belgrade, Belgrade, Serbia

e-mail: natasa.jankovic@gmail.com

\section{Towards Socially Responsible Architectural Education}

\begin{abstract}
In higher education architecture is traditionally considered either an artistic or an engineering discipline, while its other aspects (sociological, economic or ecological) are overlooked or neglected. Based on the results of the research carried out at the Faculty of Architecture in Belgrade (Master of Architecture programme) during the elective course "Re-Birth: New life of abandoned spaces", this article examines how, shifting from a strict academic framework, architectural education can contribute to the formation of expert, versatile and socially responsible architects. The idea of the course was to position a specific place and its community within the structure of architectural mechanism, rather than look at it in a merely physical context where the community is an obstacle and a burden. When we sum up the working method and the interpretative potential of the subject through students' works, the research discussion points to the value of the "learning based on the place" method in architectural education and possible ways of strengthening the connections between the place, the local community and architecture. The role of architecture is to open up space for dialogue which will help improve the heritage and advance the local community. Three facts emerge from the research. Firstly, the role of architecture can change by redefining its attitude to man and place and thus encouraging the social interaction. Secondly, the characteristics of architecture should change according to the purpose and significance of a particular place - the cultural landscape is shaped in such a way that the most striking components of architectural intervention are sound, smell, touch, light and shade, the psychological experience of space. And finally, architectural intervention should optimally shape a concrete place with regard to its population and cultural and historical references.
\end{abstract}

Key words: architectural education, social responsibility, specific characteristics of a place. 